$\begin{array}{ll}\text { Research Square } & \begin{array}{l}\text { Preprints are preliminary reports that have not undergone peer review. } \\ \text { They should not be considered conclusive, used to inform clinical practice, } \\ \text { or referenced by the media as validated information. }\end{array}\end{array}$

\title{
Effects of Ontogenetic Development on Seedling Regeneration Dynamics of Quercus Acutissima Plantation in Mount Tai
}

\author{
Longmei Guo \\ Shandong Agricultural University \\ Zexiu Li \\ Shandong Agricultural University \\ Qingzhi Lin \\ Shandong Agricultural University
}

Peili Mao ( $\square$ maopl1979@163.com )

Taishan Mountain Forest Ecosystem Research Station, Key Laboratory of State Forestry Administration for Silviculture of the lower Yellow River, Shandong Agricultural University, Tai'an 271018, China

Banghua Cao

Shandong Agricultural University

Caiyun Yu

Shandong Agricultural University

Peng Gao

Shandong Agricultural University

Jinwei Dong

Shandong Agricultural University

Boping Zhao

Mount Taishan Management Committee

\section{Research article}

Keywords: Natural regeneration, Seedling bank, Ontogenesis, Biomass allocation, Nonstructural carbohydrates

Posted Date: December 10th, 2020

DOI: https://doi.org/10.21203/rs.3.rs-123511/v1

License: (a) (i) This work is licensed under a Creative Commons Attribution 4.0 International License. Read Full License 


\section{Abstract}

Background: Natural regeneration is critically important for the sustainable management of artificial forests. Studies have been investigated for the effects of seedlings height distribution and ontogenetic adaptability in a 60-year-old Quercus acutissima artificial pure forest in Mount Tai.

Results: The results showed that the height distribution of seedlings under the forest was pyramidal-shape from the year 2010 to 2017 . In 2017 , the density of seedlings under the forest was only $61.63 \%$ of that in 2010 , and the number of individuals at each height class was lower than that in 2010 , especially the individuals at $20-40 \mathrm{~cm}$ height class only $32 \%$ of that in 2010 . With the increase of seedling height under the forest, seedling biomass (SB), ground diameter $(G D)$, root mass ratio (RMR), total root length (TRL), root volume (RV), root average diameter (RAD) and nonstructural carbohydrates (NSC) increased significantly, but leaf mass ratio (LMR), leaf area ratio (LAR), photosynthetic/non-photosynthetic tissue ratio (P/NP), specific root length (SRL) and specific root surface area (SRA) decreased significantly. Correlation analysis showed that SB was negatively correlated with LMR, LAR, P/NP, SRL and SRA, and positively correlated with RMR, TRL, RV, RAD and NSC. NSC was negatively correlated with LMR, LAR, P/NP, SRL and SRA.

Conclusions: Therefore, with the increase of seedlings height, the increased carbon storage was helpful for the seedlings of $Q$. acutissima to survive under the forest for a long time, but the reduced ability of light interception, photosynthetic tissue ratio, water and nutrient absorption capacity contributed to their low survival ratio under the forest.

\section{Background}

Man-made forest has grown rapidly global wise from 1990 to 2015 . The percentage increase was from 4.06 to $6.95 \%$ of the total forest area between 1990 and 2015 [1]. Man-made forest is playing an increasingly crucial role in timber production, environmental improvement, landscape rehabilitation and climate change mitigation [2]. Natural regeneration is a vital for sustainable forest management. Naturally regenerated forests have the advantages of better plant establishment [3], self-regenerated material and high seedling densities [4, 5]. However, unreasonable managements make the planted forests unable to complete the natural regeneration [2, 6, 7]. Stand structure [8], litter density and grass cover [9], seedling adaptation [10, 11, 12], stand management [13, 14] and year-to-year stand conditions [15] are considered to be vital factors affecting natural forest regeneration. Natural regeneration of plantation is a long-term and complex process, which is affected by many factors. At present, the regeneration mechanisms of plantation are still poorly understood.

Sufficient seedling bank is the foundation to the success of natural forest regeneration $[16,17,18,19]$. The structure and composition of natural tree regeneration is closely related to stand density [17], canopy opening [15, 20], seedling adaptability of tree species [16, 18, 19, 21] and forest management [14]. Long term monitoring on tree seedlings revealed that the fraction of seedlings eventually reach to the sapling class is very small due to high seedling mortality $[15,22,23]$. The transformation from seedlings to saplings requires higher light intensity, which is hard to achieve under the forest. Usually the demand for light is closely related to the shade tolerance for specific trees [24]. With the increase of seedling size, the proportion of non-photosynthetic tissues to total sapling biomass increased and so as respiration costs $[25,26,27,28]$. Minimum light-demanding tree species rose with increasing seedling size, which led to the decrease of shade tolerance [29,30]. Kunstler et al. [31]considered that strong morphological adaptation was an important reason for long-term survival of Fagus sy/vatica seedlings under forest. However, Sinz et al. [18] suggested the establishment and persistence of Fraxinus pennsy/vanica seedlings beneath closed canopies showed no significant relationships with their morphological adaptation. Soto et al. [32] thought light and nitrogen interact to influence regeneration in old-growth Nothofagus-dominated forests in south-central Chile. Therefore, the current understanding of the dynamics of seedling banks under forest is still very limited.

Nonstructural carbohydrates (NSC) storage is a fundamental process that allows organisms to meet variable demand for resources during their development and buffer environmental fluctuations in resource supply. Phenology is a key factor influencing seasonal variability of NSC concentrations in trees [25, 33]. Reduced NSC reserve in the root system of Populus tremuloides and $P$. balsamifera seedlings during severe drought contributed to the root death of seedlings during the dormant season by compromising the frost tolerance of the root system[34]. In shaded forest understories, NSC in tree seedlings would act like a buffer during the periods of negative net carbon balance against herbivores and diseases [35], defoliated [36] and suddenly shade increase [37], etc. Under severe shading, NSC in seedlings will be greatly consumed [38,39], or even with very little remaining [38], which determines the survival time under the forest. However, Piper et al. [40] suggested that carbohydrate storage was not related to low-light survival in Nothofagus species, but supported the view that understory survival is primarily a function of net carbon gain. Imaji and Seiwa [41] found Quercus preferentially invested more carbon in defense than in storage. In addition, some studies have shown that the effects of NSC on seedling survival are related to water stress [39], seedling size [42], defoliation [35], and forest type [43]. Therefore, the relationship between NSC and survival of seedlings has not yet formed a unified understanding.

China has the largest plantation area in the world. For a long time, plantation management pays too much attention to short-term productivity and economic benefits, but ignores its natural regeneration [2]. Quercus acutissima, a deciduous tree belonging to Quercus in Fagaceae Family, is the main component tree of forest vegetation in warm temperate and subtropical regions of China, a pioneer tree in barren mountains and barren land and an excellent tree species for soil and water conservation, with high ecological, economic and landscape values. At present, there are few studies on natural regeneration of $Q$. acutissima plantation. Q. acutissima has certain shade tolerance, and its seedlings rarely die under more than $12 \%$ full light [44]. Xue et al. [45] found there are a large number of seedlings in the secondary forest of $Q$. acutissima, but there are few saplings. In order to further explain the restriction mechanism of natural regeneration of $Q$. acutissima plantation, this paper takes the artificial pure forest of $Q$. acutissima, the main forest type of Mount Tai as the research object, and two questions were addressed: (1) the structural change of $Q$. acutissima seedlings under the forest in a long-term period; (2) how seedlings adapt with the individual growth.

\section{Results}

The diameter structure of $\mathrm{Q}$. acutissima plantation 
The density of Q. acutissima adult trees in 2010 stands was $634 \mathrm{~N} \mathrm{ha}^{-1}$, trees in the DBH class $2-5 \mathrm{~cm}$ accounting for $19.70 \%, 5-10 \mathrm{~cm}$ only for $3.44 \%$, and 15 $35 \mathrm{~cm}$ for $70.94 \%$. In 2017 , the density of adult trees was $675 \mathrm{~N} \mathrm{ha}^{-1}$, trees in the DBH $2-5 \mathrm{~cm}$ accounting for $14.81 \%, 5-10 \mathrm{~cm}$ for 0 , and $15-35 \mathrm{~cm}$ for $77.78 \%$. In 2017 , compared with 2010 , the density of trees in the DBH $2-5 \mathrm{~cm}$ decreased by $4.89 \%, 5-10 \mathrm{~cm}$ trees disappeared, and the density of $15-35 \mathrm{~cm}$ trees increased by $6.84 \%$ (Fig. 1A).

The distribution of seedlings in 2010 and 2017 was pyramid-shaped (Fig. 1B). The tree number in the height class $0-20 \mathrm{~cm}$ and $20-40 \mathrm{~cm}$ showed the maximum, and then gradually decreased with the height increasing. Compared with 2010, the density of seedlings in 2017 was only $61.63 \%$ of that in 2010 , showing a significant decrease. Moreover, seedlings of all height levels were reduced, especially at the height of $20-40 \mathrm{~cm}$, which was only $32 \%$ of that in 2010 . All seedlings at $140-150 \mathrm{~cm}$ died in 2017.

\section{Seedling size traits with the increase of height}

The results of variance analysis showed that seedling height had a significant effect on biomass $(F=17.53, P<0.01)$ and ground diameter $(F=12.56, P<$ 0.01). Biomass and ground diameter increased significantly with height (Fig. 2A and B).

\section{Adaptation traits of seedlings with increasing height Biomass allocation}

The results of variance analysis showed that seedling height had significant effects on $L M R(F=9.98, P<0.01), R M R(F=8.41, P<0.01), L A R(F=7.16, P<$ $0.01), P / N P(F=8.72, P<0.01)$, but not on SMR $(F=1.79, P=0.20)$ and SLA $(F=0.07, P=0.98)$. With the increase of height, $L M R, L A R$ and $P / N P$ all increased first and then decreased (Fig. 3A, E, F), but RMR decreased first and then increased (Fig. 3B).

\section{Root traits}

The results of variance analysis showed that seedling height had significant effects on total root length $(F=4.10, P<0.05)$, root volume $(F=31.47$, $P<0.01)$, average root diameter $(F=76.12, P<0.01)$, specific root length $(F=14.40, P<0.01)$, but not on specific root surface area $(F=1.47, P=0.27)$. With the increase of tree height, the total root length, root volume and average root diameter increased significantly, while the specific root length and root surface area decreased significantly (Fig. 5).

\section{Non-structural carbohydrate (NSC)}

The results of variance analysis showed that height had significant effects on the NSC content of root $(F=17.96, P<0.01)$, stem $(F=21.73, P<0.01)$ and leaf $(F=26.52, P<0.01)$. With the increase of tree height, NSC content of root, stem and leaf all increased significantly (Fig. 5). NSC of root was about that of leaf, and both of which were greater than that of stem.

\section{Correlation analysis among seedling traits}

SB was negatively correlated with LMR, LAR, P / NP, SRL and SRA, and positively correlated with RMR, TRL, RV, RAD and NSC (Table 2). LMR, LAR and P/NP were negatively correlated with RMR, TRL, RV and RAD. NSC was negatively correlated with LMR, LAR, P / NP, SRL and SRA, and positively correlated with RMR, TRL, RV and RAD. 
Table 1

Seedling indexes, abbreviations and units

\begin{tabular}{|c|c|c|}
\hline Indexes & Abbreviations & Units \\
\hline Seedling biomass (leaf + stem + root mass) & SB & g \\
\hline Leaf mass ratio (leaf dry mass/total seedling dry mass) & LMR & $g \cdot g^{-1}$ \\
\hline Stem mass ratio (stem + petiole mass)/total plant mass & SMR & g.g. $g^{-1}$ \\
\hline Root mass ratio (root dry mass/total seedling dry mass) & RMR & $g . g^{-1}$ \\
\hline Specific leaf area (total leaf area/total leaf dry mass) & SLA & $\mathrm{cm}^{2} \cdot \mathrm{g}^{-1}$ \\
\hline Leaf area ratio (total leaf area/total seedling dry mass) & LAR & $\mathrm{cm}^{2} \cdot \mathrm{g}^{-1}$ \\
\hline Photosynthetic tissues/non-photosynthetic tissues [leaf mass/(stem + root mass)] & $\mathrm{P} / \mathrm{NP}$ & $g \cdot g^{-1}$ \\
\hline Total Root length & TRL & $\mathrm{cm}$ \\
\hline Root volume & RV & $\mathrm{cm}^{3}$ \\
\hline Root average diameter & RAD & $\mathrm{mm}$ \\
\hline Root total surface area & RSA & $\mathrm{cm}^{2}$ \\
\hline Specific root length (root length/dry root mass) & SRL & $\mathrm{cm} \mathrm{g}^{-1}$ \\
\hline Specific root area (root surface area/ dry root mass) & SRA & $\mathrm{cm}^{2} \cdot \mathrm{g}^{-1}$ \\
\hline Root NSC & RNSC & $\mathrm{mg} \cdot \mathrm{g}^{-1}$ \\
\hline Stem NSC & SNSC & $\mathrm{mg} \cdot \mathrm{g}^{-1}$ \\
\hline Leaf NSC & LNSC & $\mathrm{mg} \cdot \mathrm{g}^{-1}$ \\
\hline
\end{tabular}


Table 2

Correlations among seedling characteristics of Quercus acutissima. SB: seedling biomass; LMR: leaf mass ratio; RMR: root mass ratio; SMR: stem mass ratio; LAR: leaf area ratio; TRL: total root length; TRA: total root surface area; RV: root volume; RAD: root average diameter; SRL: specific root length; SRA: specifi photosynthetic tissues/ non-photosynthetic tissues; RNSC: root nonstructural carbohydrate concentration; SNSC: stem nonstructural carbohydrate concen

\begin{tabular}{|c|c|c|c|c|c|c|c|c|c|c|c|c|c|c|}
\hline Indexes & SB & LMR & RMR & SMR & SLA & LAR & TRL & TRA & RV & RAD & SRL & SRA & $\mathrm{P} / \mathrm{NP}$ & RNSC \\
\hline SB & 1 & & & & & & & & & & & & & \\
\hline LMR & $-0.706^{\star *}$ & 1 & & & & & & & & & & & & \\
\hline RMR & $0.666^{* *}$ & $-0.895^{\star *}$ & 1 & & & & & & & & & & & \\
\hline SMR & -0.335 & 0.374 & $-0.748^{\star *}$ & 1 & & & & & & & & & & \\
\hline SLA & -0.053 & -0.162 & 0.146 & -0.062 & 1 & & & & & & & & & \\
\hline LAR & $-0.701^{\star *}$ & $0.923^{\star \star}$ & $-0.810^{\star *}$ & 0.312 & 0.223 & 1 & & & & & & & & \\
\hline TRL & $0.655^{\star \star}$ & $-0.556^{*}$ & $0.570^{\star}$ & -0.357 & -0.011 & $-0.557^{\star}$ & 1 & & & & & & & \\
\hline TRA & 0.368 & -0.184 & 0.294 & -0.338 & 0.237 & -0.088 & $0.661^{\star *}$ & 1 & & & & & & \\
\hline $\mathrm{RV}$ & $0.990^{\star \star}$ & $-0.753^{\star \star}$ & $0.701^{\star \star}$ & -0.338 & -0.019 & $-0.737^{\star \star}$ & $0.654^{\star \star}$ & 0.328 & 1 & & & & & \\
\hline RAD & $0.846^{* *}$ & $-0.718^{\star *}$ & $0.639^{* \star}$ & -0.261 & 0.024 & $-0.704^{\star *}$ & $0.649^{* *}$ & 0.255 & $0.897^{\star \star}$ & 1 & & & & \\
\hline SRL & $-0.666^{\star *}$ & 0.420 & -0.367 & 0.138 & -0.044 & 0.390 & -0.367 & -0.250 & $-0.657^{\star \star}$ & $-0.734^{\star *}$ & 1 & & & \\
\hline SRA & $-0.678^{\star \star}$ & 0.475 & -0.450 & 0.230 & 0.015 & 0.472 & $-0.630^{\star *}$ & -0.346 & $-0.671^{\star *}$ & $-0.769^{\star \star}$ & $0.927^{\star *}$ & 1 & & \\
\hline $\mathrm{P} / \mathrm{NP}$ & $-0.669^{\star \star}$ & $0.998^{\star \star}$ & $-0.888^{\star \star}$ & 0.361 & -0.178 & $0.917^{\star *}$ & $-0.540^{*}$ & -0.168 & $-0.719^{\star \star}$ & $-0.693^{\star *}$ & 0.389 & 0.447 & 1 & \\
\hline RNSC & $0.774^{\star \star}$ & $-0.575^{*}$ & $0.542^{*}$ & -0.271 & -0.053 & $-0.601^{*}$ & $0.739^{\star \star}$ & 0.423 & $0.780^{\star \star}$ & $0.841^{\star *}$ & $-0.751^{\star *}$ & $-0.847^{\star *}$ & $-0.554^{*}$ & 1 \\
\hline SNSC & $0.791^{\star *}$ & $-0.569^{\star}$ & $0.486^{*}$ & -0.164 & -0.133 & $-0.623^{\star *}$ & $0.661^{\star *}$ & 0.384 & $0.806^{\star *}$ & $0.847^{\star \star}$ & $-0.705^{\star *}$ & $-0.757^{\star \star}$ & $-0.547^{\star}$ & 0.932 \\
\hline LNSC & $0.815^{\star \star}$ & $-0.670^{\star \star}$ & $0.541^{*}$ & -0.128 & -0.065 & $-0.701^{\star *}$ & $0.687^{\star \star}$ & 0.364 & $0.838^{\star \star}$ & $0.884^{\star \star}$ & $-0.708^{\star \star}$ & $-0.761^{\star \star}$ & $-0.651^{\star \star}$ & 0.951 \\
\hline
\end{tabular}

\section{Discussion}

The seedling density of Q. acutissima plantation in this paper was $14063 \mathrm{~N} \mathrm{ha}^{-1}$ in 2010 and $8667 \mathrm{~N} \mathrm{ha}^{-1}$ in 2017 . According to the Austrian forest inventory, regeneration densities on sites with less than 2,500 trees $^{-1} \mathrm{a}^{-1}$ are classified as insufficient [46]. Therefore, there are sufficient seedlings under the $Q$. acutissima plantation, which is related to the ability of shade tolerance in seedling stage [44]. The distribution of seedlings in 2010 and 2017 was pyramidshaped, indicating that the seedling bank was relatively stable. The seedling density in the height class $0-20 \mathrm{~cm}$ in 2010 was similar to that in 2017 , which was related to the continuous germination of seeds under the forest [22, 47]. Compared with 2010, the stand density changed little in 2017, but the seedling density decreased significantly, only $61.63 \%$ of that in 2010 . Szwagrzyk et al. [22] also found seedlings of Fagus syvatica which could eventually enter the sapling stage in submontane beech-dominated forests is very small due to high mortality at very low light levels under closed canopies. Many studies have shown that the conversion rate from seedlings to saplings is very low due to the insufficient relative light intensity under the forest for long-term survival [15, $22,23,47]$. Studies on natural regeneration of Quercus suggested that higher light intensity was needed for successful regeneration [17, 21]. Therefore, relatively low light intensity may be an important reason for the gradual death of $Q$ acutissima seedlings under the forest.

With increasing size, LMR and LAR decreased significantly in $Q$. acutissima seedlings in this paper, which indicated that the light utilizing efficiency decreased. This result was consistent with that of Balandier et al. [27] and Lusk [48]. However, Sinz et al. [18] found that Fraxinus pennsy/vanica regeneration maintains a fixed morphology relative to size through seedling and sapling development. In this paper, P/NP of $Q$. acutissima seedlings decreased as tree size increased, which was in good agreement with the results reported by Balandier et al. [27] and Gaucher et al. [25]. The proportion of non-photosynthetic tissues increases with increasing seedling size causes an increase in respiratory and construction costs in large individuals, which leads to the increase of minimum light requirement $[25,29,30]$. The increase of minimum light requirement in taller seedlings is a vital reason for the low understory survival for light demanding trees species [29,30]. Grubb [49] proposed that tree species by maximizing net carbon gain in low light could persist in the understory for a long time. With the increase of seedling height, the increasing RAD indicated that the fraction of fine roots decreased. The significant decrease of SRL and SRA with increasing height indicated the ability of root system to absorb water and nutrients decreased [50]. Correlation analysis showed that SB was negatively correlated with LMR, LAR, P/NP, SRL and SRA. Therefore, with the increase of seedling size, the decrease of the light utilizing efficiency, the proportion of non-photosynthetic tissue and the absorption capacity of root system are an important reasons to limit the long-term survival of $Q$. acutissima seedlings under the forest. 
With the increase of height, the concentration of NSC in Q. acutissima seedlings increased, which agreed with the results reported by Lusk and Piper [42]. SB of $Q$. acutissima was significantly positively correlated with NSC concentration, suggesting a progressive accumulation of carbohydrate reserves during seedling development. Some studies have shown that the higher the content of NSC in the seedlings, the longer the survival time under shade [35, 38, 39]. Furthermore, carbohydrate storage in stems and roots enhances long-term survival in shade by enabling seedlings to cope with periods of biotic and abiotic stress [35, 42]. Q. acutissima seedlings also showed high content of NSC in roots, which was positively related to TRL, RV and RAD. Therefore, the long-term survival of $Q$. acutissima seedlings under the forest is closely related to the high level of NSC in roots. However, NSC was negatively correlated with LMR, LAR, $\mathrm{P} / \mathrm{NP}$, SRL and SRA, which indicated that there was competition between NSC storage and light utilization capacity, the proportion of photosynthetic tissue and root absorption capacity, that is, there was a trade-off between carbon storage and growth. Therefore, with the increase of individual size, sacrificing growth and increasing carbon storage can improve the persistence time of $Q$. acutissima seedlings under the forest.

\section{Conclusion}

The natural regeneration of plantation is a complex and long process, and the adaptability of seedlings under the forest is one of the key foundations for its successful regeneration. In the sample plot of $Q$. acutissima plantation, the seedling bank was sufficient and stable, which was closely related to its shade tolerance. With the increase of height, the RMR and NSC content of seedlings increased, which was helpful for their long-term persistence under the forest. However, compared with the seedling bank in 2010, the number of seedlings decreased significantly in 2017. With the increase of height, the capacity of light utilization, the fraction of photosynthetic tissue and the capacity of water and nutrient absorption decreased significantly. Eventually the significant decrease of LMR, LAR, P/NP, SRL and SRA led to the survival failure of $Q$. acutissima seedlings in the forest. The study on natural regeneration of other Quercus trees shows that higher light intensity is needed for successful regeneration. Therefore, it is necessary to further study the relationship between natural regeneration and light environment of $Q$. acutissima plantation, and clarify the light intensity range of successful natural regeneration, so as to provide theoretical basis for the sustainable management of $Q$. acutissima plantation.

\section{Methods \\ Study area}

Mount Tai lies in the middle of Shandong province, China, between Jinan and Tai 'an. The study area belongs to the warm temperate continental monsoon climate zone, the average annual temperature is $12.6^{\circ} \mathrm{C}$, the frost-free period is 196 days, and the accumulated temperature greater than or equal to $10^{\circ} \mathrm{C}$ is $3821^{\circ} \mathrm{C}$. The average annual precipitation is $758 \mathrm{~mm}$, and the precipitation is centered from June to September. The soil type is mainly brown loam with $\mathrm{pH}$ value of about 6.0 and soil thickness of $15 \sim 60 \mathrm{~cm}$. Most of the vegetation in Mount Tai was planted in the 1950s and 1960s, with a total forest area of about $9,490 \mathrm{hm}^{2}$ and a forest coverage rate of $81.5 \%$. The main tree species include Platycladus orientalis, Q. acutissima, Robinia pseudoacacia, Pinus thunbergii, Pinus densiflora, Pinus tabuliformis, etc [51, 52].

\section{Investigation of Q. acutissima plantation}

The investigation of Q. acutissima plantation was conducted in the Mountain Tai Forest Ecosystem Research Station of State Forestry and Grassland Administration ( $\left.117^{\circ} 06^{\prime} 48.2^{\prime \prime} \mathrm{N}, 36^{\circ} 20^{\prime} 05.3^{\prime \prime} \mathrm{E}\right)$, whose technical support unit is Shandong Agricultural University. The forest was artificially planted in 1960 using one-year-old seedlings from seeds collected from Q. acutissima forest in Mount Tai. The plantation is a pure forest with an age of 60a and locates at $730 \mathrm{~m}$. The permanent fixed plot was established in 2010 with an area of $0.48 \mathrm{hm}^{2}$. Twelve $20 \mathrm{~m} \times 20 \mathrm{~m}$ quadrates were set up in the fixed plot. In each quadrat, we measured the diameter at breast height (DBH) for all trees with height $\geq 150 \mathrm{~cm}$, which were defined as adult trees. Saplings below $1.5 \mathrm{~m}$ in height were divided into 8 levels according to the height: $<20 \mathrm{~cm}, 20-40 \mathrm{~cm}, 40-60 \mathrm{~cm}, 60-80 \mathrm{~cm}, 80-100 \mathrm{~cm}, 100-120 \mathrm{~cm}, 120-140 \mathrm{~cm}$ and $140-150 \mathrm{~cm}$. Adult trees were classified into DBH sizes, with one diameter class for every $5 \mathrm{~cm}$. The permanent fixed plot was reviewed in May 2017. The sampling and investigation methods in this paper referred to the forestry industry standard of the People's Republic of China issued by the State Forestry Administration [53]. The formal identification of the samples was undertaken by the corresponding author Peili Mao, and the specimen information of the species involved in this study are available at "China Plant Species Information System".

\section{Determination of seedling traits of Q. acutissima}

On May 10, 2016, 19 seedlings with a height between 9 and $46 \mathrm{~cm}$ were selected and dug out in Q. acutissima plantation of Yaoxiang forest farm. These seedlings were divided into 4 groups according to height: $5 \mathrm{~cm}<$ height $<15 \mathrm{~cm}$ (I), $16 \mathrm{~cm}<$ height $<25 \mathrm{~cm}$ (II), $26 \mathrm{~cm}<$ height $<35 \mathrm{~cm}$ (III), $36 \mathrm{~cm}<$ height $<$ $45 \mathrm{~cm}$ (IV). And there were 3-5 seedlings within each height group. The height, diameter and number of leaves of the seedlings were measured. Then, each seedling was carefully excavated from soil with hand tools and the whole $Q$. acutissima seedling was sealed and stored in a self-sealing bag and brought back to the laboratory.

In the laboratory, the seedlings were divided into leaves, stems and roots. The age of seedlings was determined by counting the number of annual rings. The area of each leaf of each seedling was measured one by one with $\mathrm{Cl}-202$ portable laser leaf area meter (CID Inc., Washington, USA). After being rinsed with clean water, these roots were scanned by HP Scanjet 8200 scanner, and the scanned images were analyzed by root parameter analysis software (Delta-T Area Meter Type AMB2) to obtain length and surface area of roots. The roots, stems and leaves of seedlings were dried at $80^{\circ} \mathrm{C}$ until constant weight, then the dry weight was weighed and recorded. After dried samples of roots, stems and leaves were pulverized, their concentrations of soluble sugar and starch were determined by anthranone $-\mathrm{H}_{2} \mathrm{SO}_{4}$ colorimetry, respectively [54]. Starch and soluble sugars in each plant organ were added together to determine nonstructural carbohydrate concentration (NSC).

\section{Statistical analysis}


The seedling indexes were shown in Table 1. Relevant data were analyzed by SPSS20.0 (SPSS Inc., Chicago, USA) statistical analysis software for one-way ANOVA. The responses of functional traits to height were compared and multiple comparisons were made. At the same time, the correlation analysis of each index is carried out. The test level was $\mathrm{P}=0.05$.

\section{Abbreviations}

SB

Seedling biomass (leaf + stem + root mass)

LMR

Leaf mass ratio (leaf dry mass/total seedling dry mass)

SMR

Stem mass ratio (stem + petiole mass)/total plant mass

RMR

Root mass ratio (root dry mass/total seedling dry mass)

SLA

Specific leaf area (total leaf area/total leaf dry mass)

LAR

Leaf area ratio (total leaf area/total seedling dry mass)

P/NP

Photosynthetic tissues/non-photosynthetic tissues [leaf mass/(stem + root mass)]

TRL

Total Root length

RV

Root volume

RAD

Root average diameter

RSA

Root total surface area

SRL

Specific root length (root length/dry root mass)

SRA

Specific root area (root surface area/ dry root mass)

RNSC

Root NSC

SNSC

Stem NSC

LNSC

Leaf NSC

\section{Declarations}

\section{Ethics approval and consent to participate}

Not applicable.

\section{Consent for publication}

Not applicable.

\section{Availability of data and material}

All of the data and materials supporting our research findings are contained in the methods section of the manuscript.

\section{Competing interests}

The authors declare that they have no competing interests.

\section{Funding}

This research was sponsored by the Key R \& D project of Shandong Province, China (2017CXGC0316) and Funds of the Shandong "Double Tops Program" (SYL2017XTTD09). The funders had no role in study design, data collection and analysis, decision to publish, or preparation of the manuscript. 
PLM and BHC conceived and guided the project. PLM, LMG, ZXL and QZL conducted the experiments. LMG, ZXL, QZL, CYY, PG, JWD and BPZ collected and analyzed the data; PLM, LMG, ZXL, QZL carried out the experiments and performed software; PLM and LMG wrote the manuscript; PLM and BHC reviewed the manuscript. All authors have read and approved the final manuscript.

\section{Acknowledgements}

Not applicable.

\section{References}

1. Payn T, Carnus JM, Freer-Smith P, Kimberley M, Kollert W, Liu S, Orazio C, Rodriguez L, Silva LN, Wingfield MJ. Changes in planted forests and future global implications. For Ecol Manag. 2015;352:57-67.

2. Liu SR, Yang YJ, Wang H. Development strategy and management countermeasures of planted forests in China: Transforming from timber-centered single objective management towards multi-purpose management for enhancing quality and benefits of ecosystem services. Acta Ecol Sin. 2018;38: 1-10.

3. Mauer O, Palátová E. Root system response to stress in artificially established Norway spruce stands. Ekológia (Bratislava).2000;19:151-161.

4. Szymura TH, Dunajski A, Aman I, Makowski M, Szymura M. The spatial pattern and microsites requirements of Abies alba natural regeneration in the Karkonosze Mountains. Dendrobiology. 2007;58:51-57.

5. Jaworski A, Podlaski R. Structure and dynamics of selected stands of primeval character in the Pieniny National Park. Dendrobiology. 2007;58:25-41.

6. Agestam E, Eko PM, Nilsson U, Welander NT. The effects of shelterwood density and site preparation on natural regeneration of Fagus sylvatica in southern Sweden. Forest Ecol Manag. 2003;176(1-3):61-73.

7. Madsen P, Hahn K. Natural regeneration in a beech-dominated forest managed by close-to-nature principles-a gap cutting experiment. Can J For Res. 2008;38(7):1716-1729.

8. Petritan AM, Biris IA, Merce O, Turcu DO, Petritan IC. Structure and diversity of a natural temperate sessile oak (quercus petraea L.) - european beech (fagus sylvatica L.) forest. For Ecol Manag. 2012;280:140-149.

9. Proll G, Darabant A, Gratzer G, Katzensteiner K. Unfavourable microsites, competing vegetation and browsing restrict post-disturbance tree regeneration on extreme sites in the northern calcareous alps. Eur J For Res. 2015;134(2):293-308.

10. Valladares F, Niinemets Ü. Shade tolerance, a key plant feature of complex nature and consequences. Annu Rev Ecol Evol Syst. 2008;39:237-257.

11. Jarcuska B. Growth, survival, density, biomass partitioning and morphological adaptations of natural regeneration in Fagus sylvatica. A review. Dendrobiology. 2009;61(1):3-11.

12. Valladares F, Laanisto L, Niinemets Ü, Zavala MA.Shedding light on shade: ecological perspectives of understorey plant life. Plant Ecol Divers. 2016;9(3):237-251.

13. Guariguata MR. Seed and seedling ecology of tree species in neotropical secondary forests: management implications. Ecol Appl. 2000;10(1):145-154.

14. Barna M, Bosela M. Tree species diversity change in natural regeneration of a beech forest under different management. For Ecol Manag. 2015;342:93102.

15. Pardos M, Montes F, Aranda I, Caňellas I. Influence of environmental conditions on germinant survival and diversity of Scots pine (Pinus sy/vestris L.) in central Spain. Eur J Forest Res. 2007; 126(1):37-47.

16. Szewczyk J, Szwagrzyk J. Spatial and temporal variability of natural regeneration in a temperate old-growth forest. Ann For Sci. 2010;67(2): 202.

17. Dobrowolska D. Effect of stand density on oak regeneration in flood plain forests in Lower Silesia, Poland. Forestry. 2008;81(4):511-523.

18. Sinz A, Emile S, Gardiner ES, Lockhart BR, Souter RA. Morphological acclimation and growth of ash (Fraxinus pennsy/vanica Marsh.) advance regeneration following overstory harvesting in a Mississippi River floodplain forest. For Ecol Manag. 2011;261(2):246-254.

19. Nagel TA, Svoboda M, Rugani T, Jurij Diaci J. Gap regeneration and replacement patterns in an old-growth Fagus-Abies forest of Bosnia-Herzegovina. Plant Ecol. 2010;208(2):307-318.

20. Collet C, Lanter O, Pardos M. Effects of canopy opening on the morphology and anatomy of naturally regenerated beech seedlings. Trees. 2002;16(45):291-298.

21. Petritan AM, Nuske RS, Petritan IC, Tudose NC. Gap disturbance patterns in an old-growth sessile oak (Quercus petraea L.)-European beech (Fagus sylvatica L.) forest remnant in the Carpathian Mountains, Romania. For Ecol Manag.2013; 308:67-75.

22. Szwagrzyk J, Szewczyk J, Bodziarczyk J. Dynamics of seedling banks in beech forest: results of a 10-year study on germination, growth and survival. For Ecol Manag. 2001;141(3):237-250.

23. Rey PJ, Alcántara JM. Recruitment dynamics of a fleshy-fruited plant (olea europaea): connecting patterns of seed dispersal to seedling establishment. J Ecol. 2000;88(4):622-633.

24. Gasser D, Messier C, Beaudet M, Lechowicz MJ. Sugar maple and yellow birch regeneration in response to canopy opening, liming and vegetation control in a temperate deciduous forest of Quebec. For Ecol Manag. 2010;259 (10):2006-2014.

25. Gaucher C, Gougeon S, Mauffette Y, Messier C. Seasonal variation in biomass and carbohydrate partitioning of understory sugar maple (Acer saccharum) and yellow birch (Betula alleghaniensis) seedlings. Tree Physiol. 2005;25(1):93-100.

26. Givnish TJ. Adaptation to sun and shade: perspective. Aust J Plant Physiol. 1988;15(2):63-93.

27. Balandier P, Sinoquet H, Frak E, Giuliani R, Vandame M, Descamps S, Coll L, Adam B, Prevosto B, Curt T. Six-year time course of light-use efficiency, carbon gain and growth of beech saplings (Fagus sylvatica) planted under a Scots pine (Pinus sylvestris) shelterwood. Tree Physiol. 2007;27(8):1073-1082.

Page $8 / 20$ 
28. Claveau Y, Messier C, Comeau PG. Interacting influence of light and size on aboveground biomass distribution in sub-boreal saplings with contrasting shade tolerance. Tree Physiol. 2005;25(3):373-384.

29. Lusk CH, Falster DS, Jara-Vergara CK, Jimenez-Castillo $M$, Saldaña-Mendoza A. Ontogenetic variation in light requirements of juvenile rainforest evergreens. Funct Ecol. 2008;22(3):454-459.

30. Sendall KM, Reich PB, Lusk $\mathrm{CH}$. Size-related shifts in carbon gain and growth responses to light differ among rainforest evergreens of contrasting shade tolerance. Oecologia. 2018;187(3):609-623.

31. Kunstler G, Curt T, Bouchaud M, Lepart J. Growth, mortality, and morphological response of European beech and downy oak along a light gradient in subMediterranean forest. Can J For Res. 2005;35(7):1657-1668.

32. Soto DP, Jacobs DF, Salas C, Donoso PJ, Fuentes C, Puettmann KJ. Light and nitrogen interact to influence regeneration in old-growth Nothofagusdominated forests in south-central Chile. For Ecol Manag. 2017;384:303-313.

33. Tixier A, Guzmán-Delgado P, Sperling O, Roxas AA, Laca EA, Zwieniecki MA. Comparison of phenological traits, growth patterns, and seasonal dynamics of non-structural carbohydrate in Mediterranean tree crop species. Sci Rep. 2020;10(1): 1-11.

34. Galvez DA, Landhausser SM, Tyree MT. Low root reserve accumulation during drought may lead to winter mortality in poplar seedlings. New Phytol. 2013;198(1):139-148.

35. Myers JA, Kitajima K. Carbohydrate storage enhances seedling shade and stress tolerance in a neotropical forest. J Ecol. 2007;95(2):383-395.

36. Gleason SM, Ares A. Photosynthesis, carbohydrate storage and survival of a native and an introduced tree species in relation to light and defoliation. Tree Physiol. 2004;24(10):1087-1097.

37. Veneklaas EJ, Den Ouden F. Dynamics of non-structural carbohydrates in two Ficus species after transfer to deep shade. Environ Exp Bot. 2005;54(2):148154.

38. Sevanto S, McDowell NG, Dickman LT, Pangle R, Pockman WT. How do trees die? A test of the hydraulic failure and carbon starvation hypotheses. Plant Cell Environ. 2014;37(1):153-161.

39. Deng XX, Xiao WF, Shi Z, Zeng LX, Lei L. Combined Effects of Drought and Shading on Growth and Non-Structural Carbohydrates in Pinus massoniana Lamb. Seedlings. Forests. 2020;11(1):1-16.

40. Piper Fl, Reyes-Díaz M, Corcuera LJ, Lusk CH. Carbohydrate storage, survival, and growth of two evergreen Nothofagus species in two contrasting light environments. Ecol Res. 2009;24(6):1233-1241.

41. Imaji A, Seiwa K. Carbon allocation to defense, storage, and growth in seedlings of two temperate broad-leaved tree species. Oecologia. 2010;162(2):273281.

42. Lusk $\mathrm{CH}$, Piper FI. Seedling size influences relationships of shade tolerance with carbohydrate-storage patterns in a temperate rainforest. Funct Ecol. 2007;21(1):78-86.

43. Poorter L, Kitajima K. Carbohydrate storage and light requirements of tropical moist and dry forest tree species. Ecology. 2007;88(4):1000-1011.

44. Yang Y, Wang CH, Liu YH. The effect of low irradiance on growth $\rrbracket$ photosynthetic characteristics \and biomass allocation in two deciduous broad-leaved tree seedlings in southeast of Hubei Province. Acta Ecol Sin. 2010;30(22):6082-6090.

45. Xue WY, Yang B, Zhang WH, Yu SC. Spatial pattern and spatial association of Quercus acutissima at different developmental stages in the Qiaoshan Mountains. Acta Ecologica Sinica. 2017;37(10):3375-3384.

46. Schodterer H. Verjüngung im österreichischen Wald: Defizite im Schutzwald. BFW-Praxis information. 2011;24:10-14.

47. Ammer C, Stimm B, Mosandl R. Ontogenetic variation in the relative influence of light and belowground resources on European beech seedling growth. Tree Physiol. 2008;28(5):721-728.

48. Lusk CH. Leaf area and growth of juvenile temperate evergreens in low light: species of contrasting shade tolerance change rank during ontogeny. Funct Ecol. 2004;18(6):820-28.

49. Grubb PJ. A reassessment of the strategies of plants which cope with shortages of resources. Perspect Plant Ecol Evol Syst. 1998;1(1):3-31.

50. Mao PL, Zhang YJ, Cao BH, Guo LM, Shao HB, Cao ZY, Jiang QK, Wang X. Effects of salt stress on eco-physiological characteristics in Robinia pseudoacacia based on salt-soil rhizosphere. Sci Total Environ. 2016;568:118-123.

51. Meng Y, Cao BH, Dong C, Dong XF. Mount Taishan forest ecosystem health assessment based on forest inventory data. Forest. 2019;10(8):657.

52. Meng Y, Cao BH, Mao PL, Dong C, Cao XD, Qi L, Wang MX, Wu Y. Tree species distribution change study in Mount Tai based on landsat remote sensing image data. Forest. 2020;11(2):130.

53. State Forestry Administration. LY/T 1952-2011 Observation methodology for long-term sorest ecosystem research. Beijing: China Standard Press, 2011.

54. Zhou YB, Wu DD, Yu DP, Sui C-Y. Variations of nonstructural carbohydrate content in Betula ermanii at different elevations of Changbai Mountain, China. Journal of Plant Ecology. 2009;33(001):118-124.

\section{Figures}



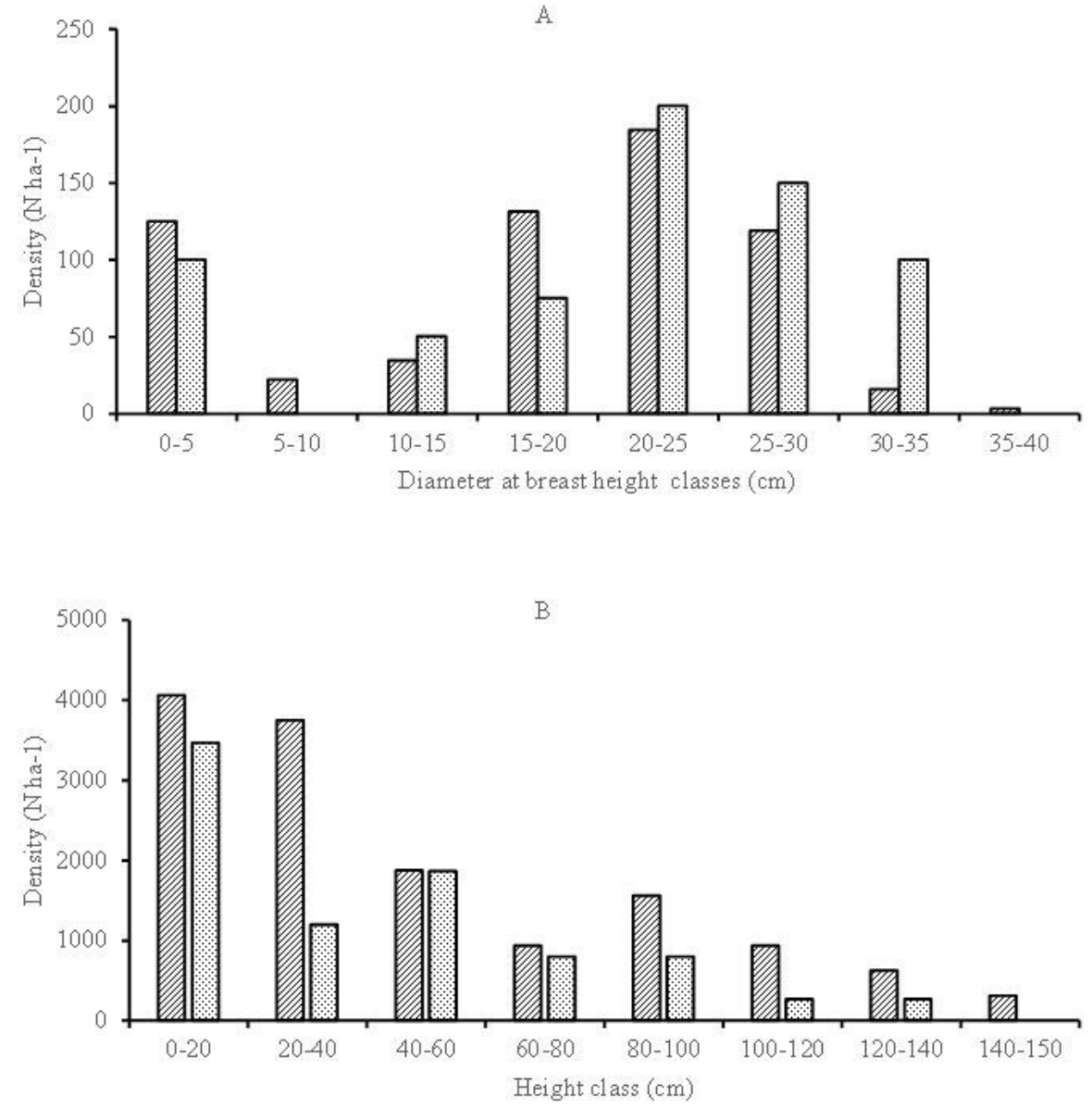

๑2010 $\mathbf{0} 2017$

\section{Figure 1}

Diameter at breast height classes of adult trees (A) and height classes of seedlings (B) distribution patterns of Quercus acutissima in 2010 and 2017 , respectively 

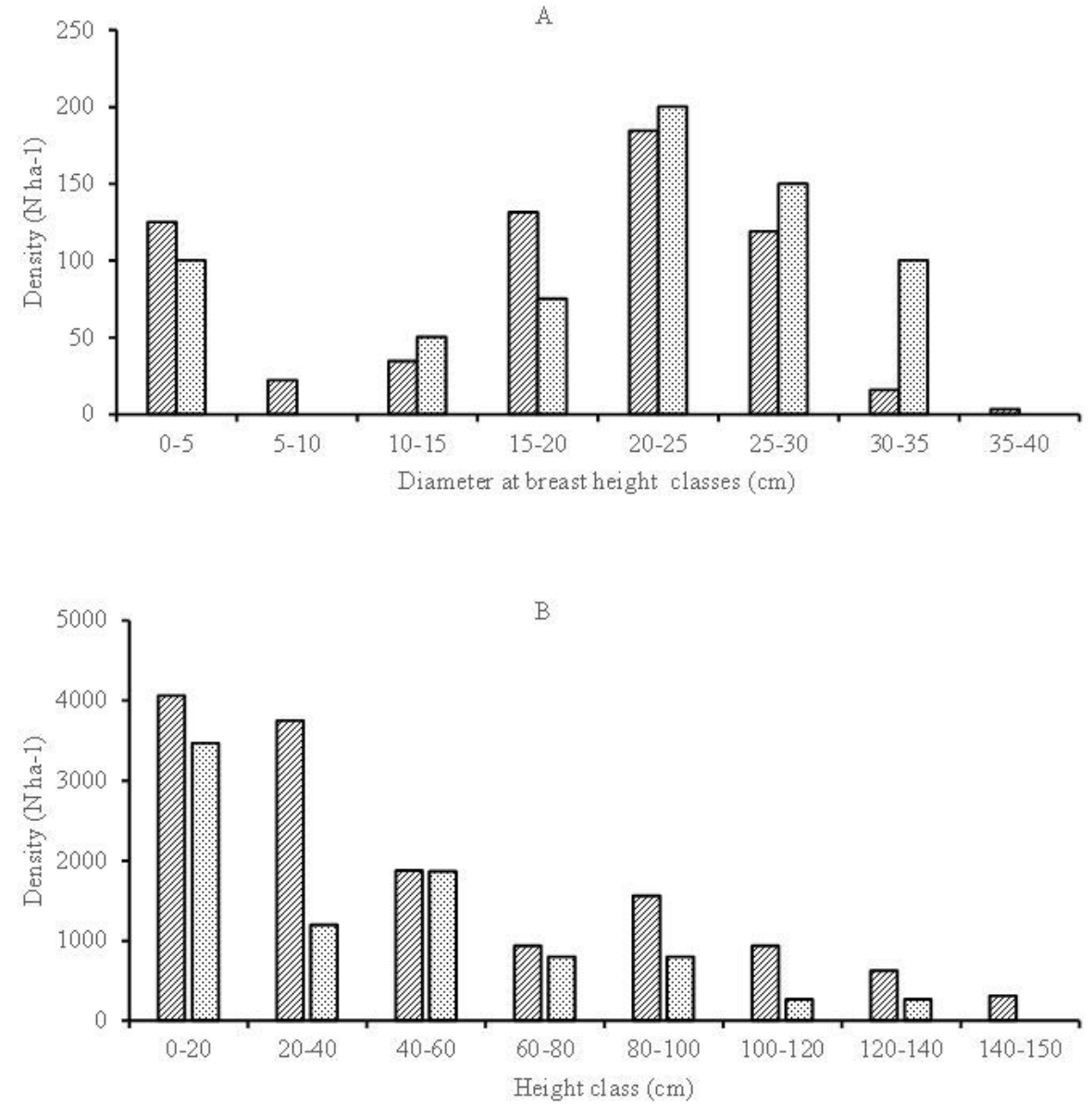

๑2010 $\mathbf{0} 2017$

\section{Figure 1}

Diameter at breast height classes of adult trees (A) and height classes of seedlings (B) distribution patterns of Quercus acutissima in 2010 and 2017 , respectively 

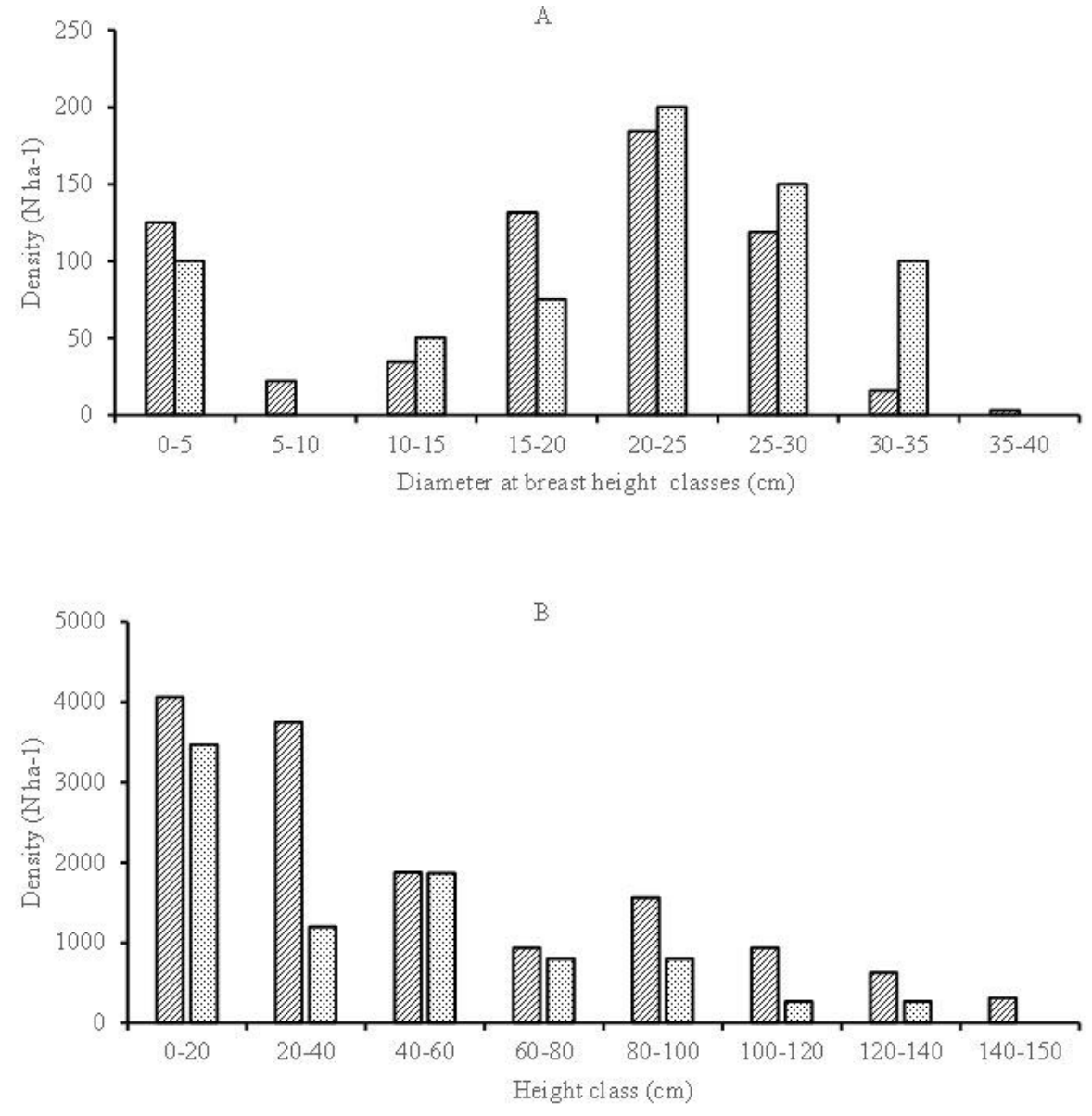

จ2010 ช2017

\section{Figure 1}

Diameter at breast height classes of adult trees (A) and height classes of seedlings (B) distribution patterns of Quercus acutissima in 2010 and 2017 , respectively

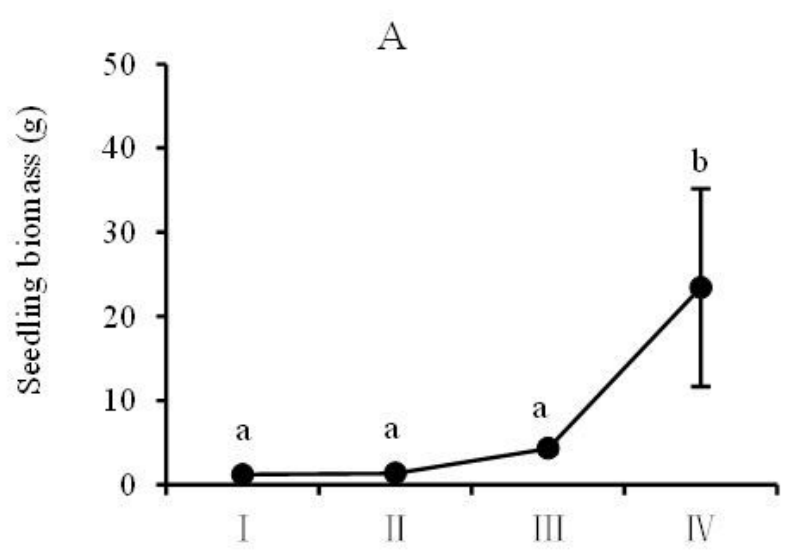

Height class
B

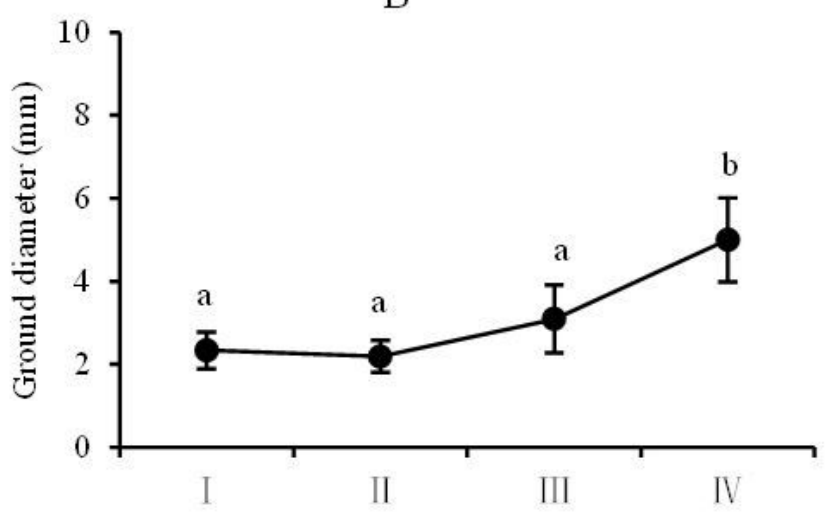

Height class

Figure 2

Changes of seedling biomass (SB, A) and ground diameter (GD, B) with the increase of seedling height of Quercus acutissima

Page $12 / 20$ 


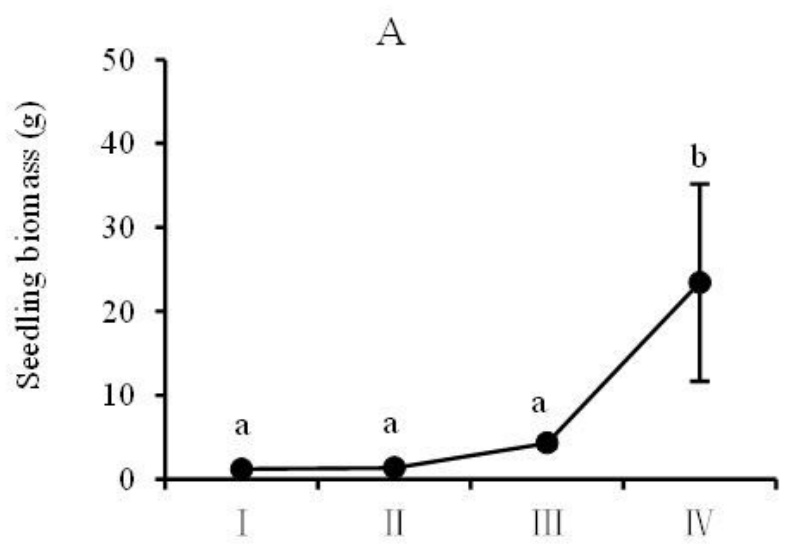

Height class
B

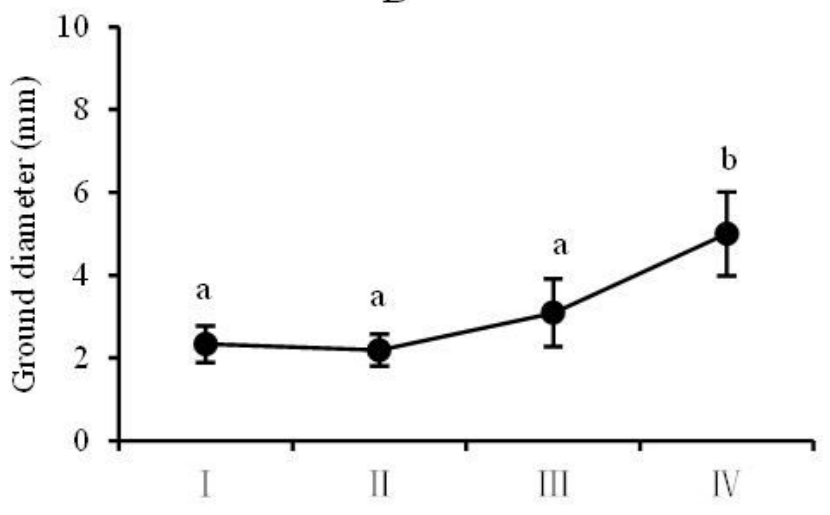

Height class

Figure 2

Changes of seedling biomass (SB, A) and ground diameter (GD, B) with the increase of seedling height of Quercus acutissima

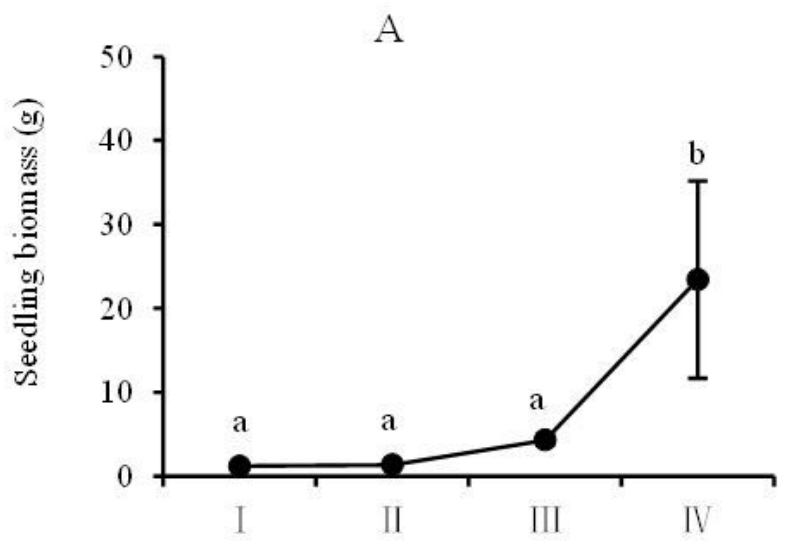

Height class
B

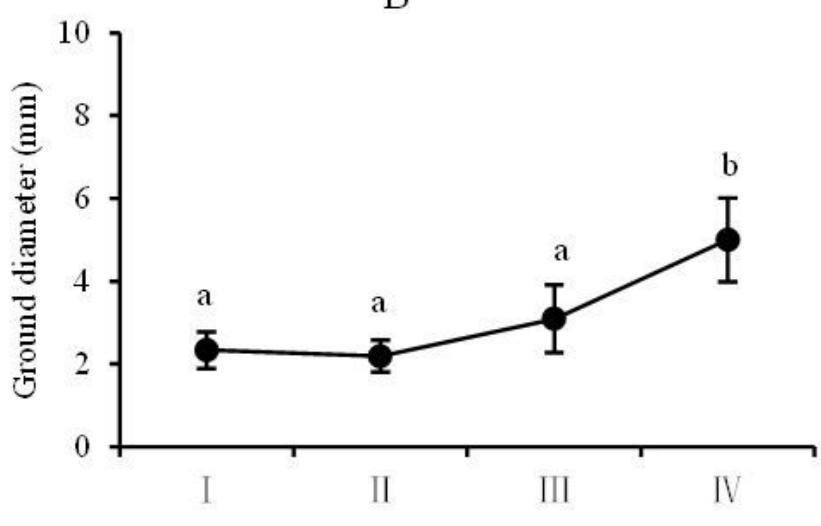

Height class

\section{Figure 2}

Changes of seedling biomass (SB, A) and ground diameter (GD, B) with the increase of seedling height of Quercus acutissima 

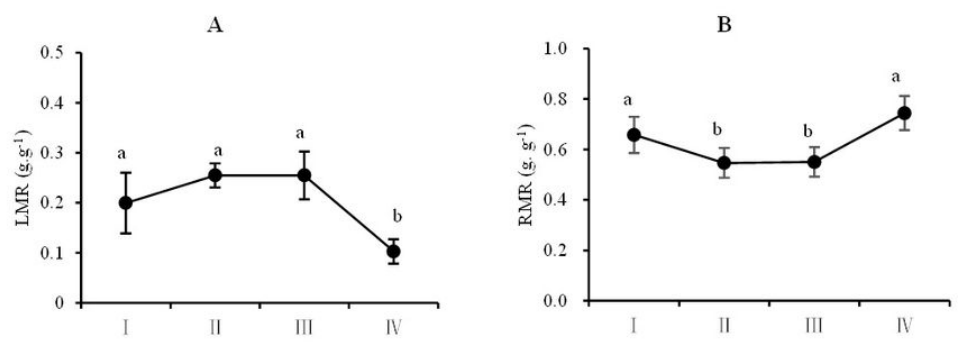

C

D
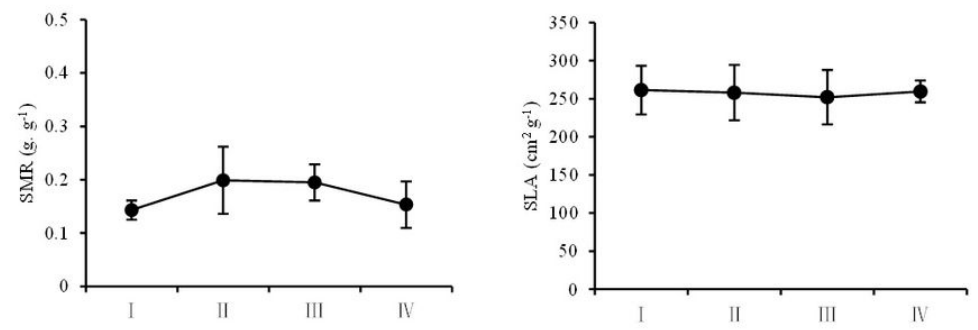

E

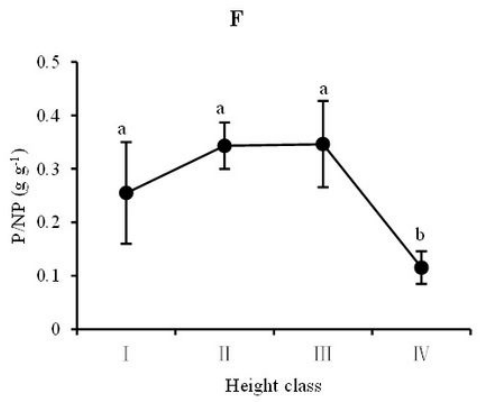

Figure 3

Changes of biomass allocation with the increase of seedling height of Quercus acutissima. A: LMR; B: RMR; C: SMR; D: SLA; E: LAR; F: P/NP 

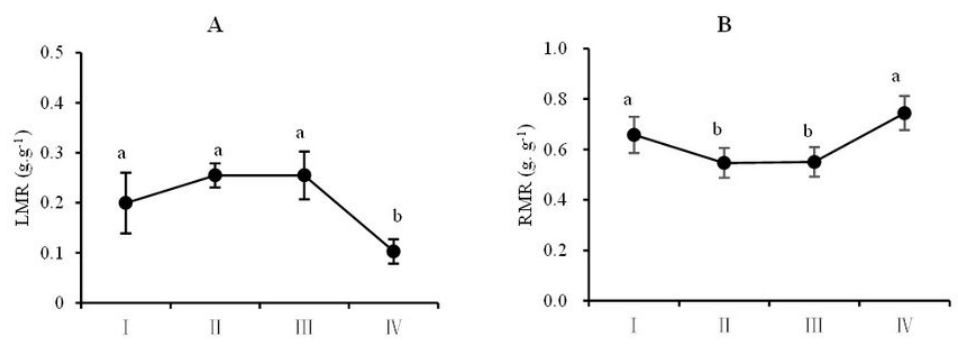

C

D
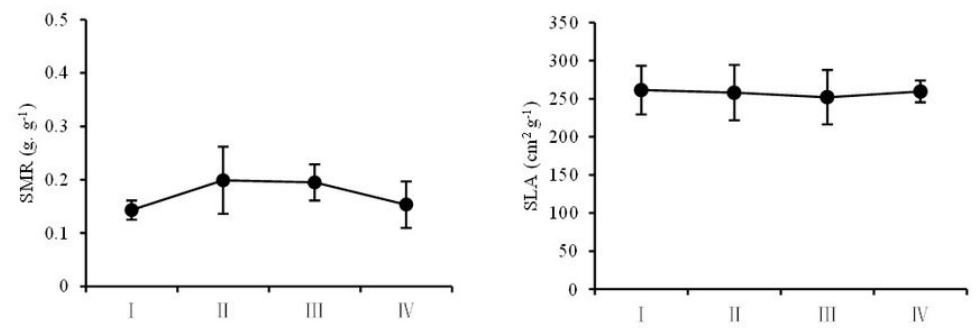

E

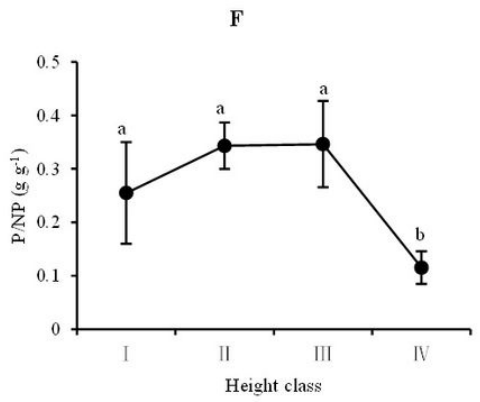

Figure 3

Changes of biomass allocation with the increase of seedling height of Quercus acutissima. A: LMR; B: RMR; C: SMR; D: SLA; E: LAR; F: P/NP 

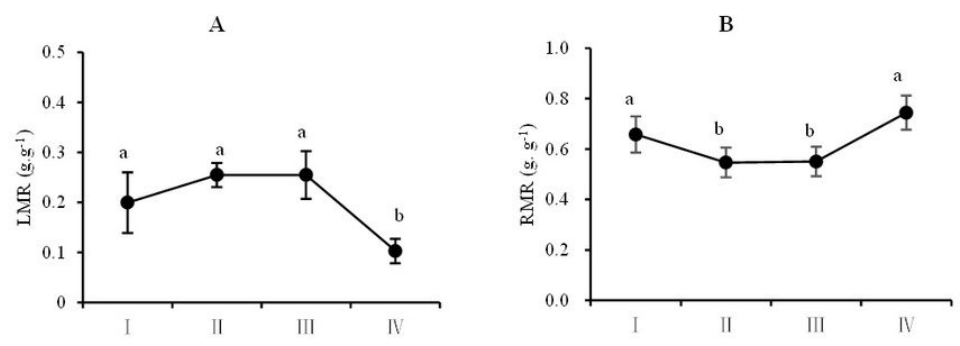

C

D
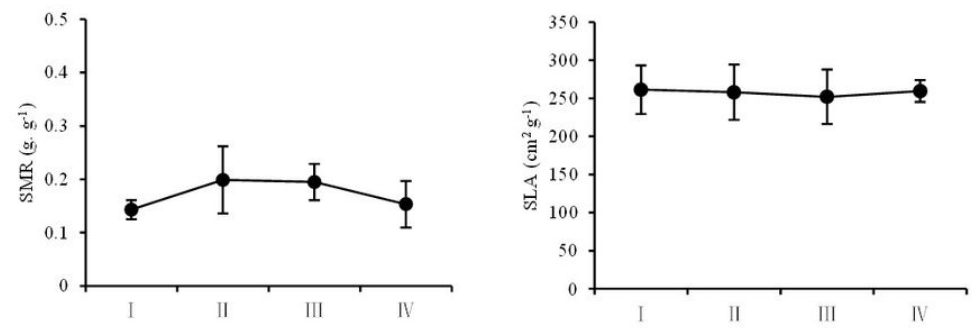

E

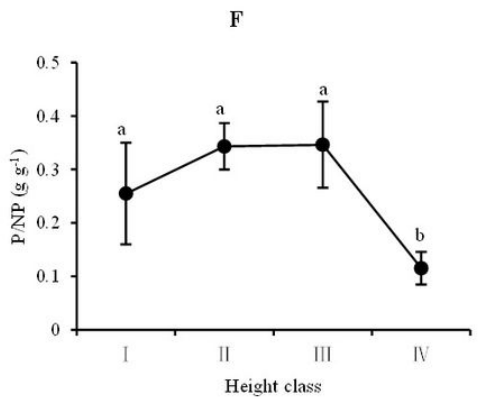

Figure 3

Changes of biomass allocation with the increase of seedling height of Quercus acutissima. A: LMR; B: RMR; C: SMR; D: SLA; E: LAR; F: P/NP 
A

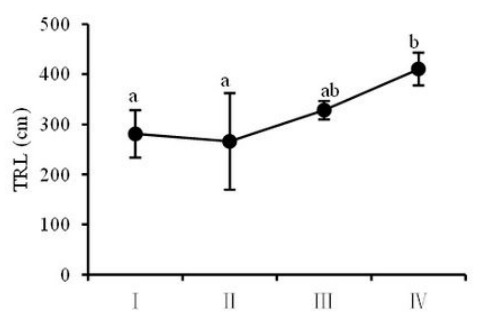

C

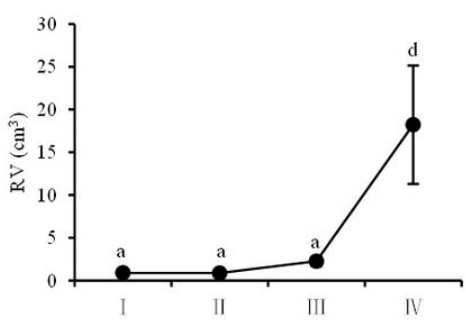

E

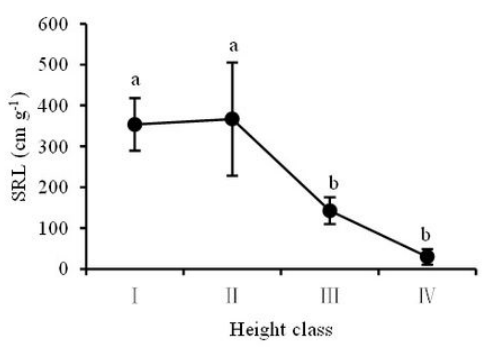

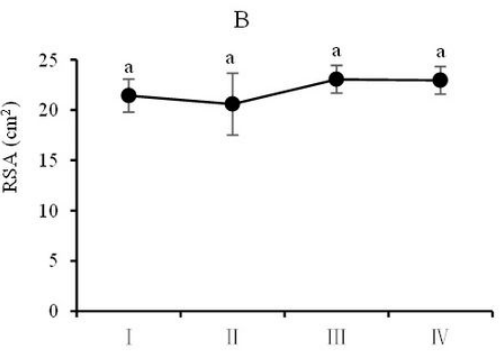

D

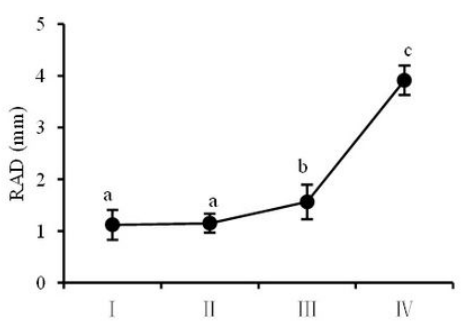

F

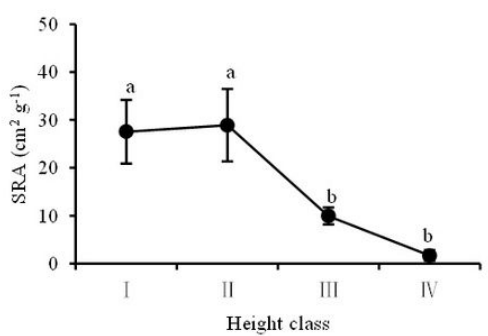

Figure 4

Changes of root traits with the increase of seedling height of Quercus acutissima. A: TRL; B: RSA; C: RV; D: RAD; E: SRL; F: SRA 
A

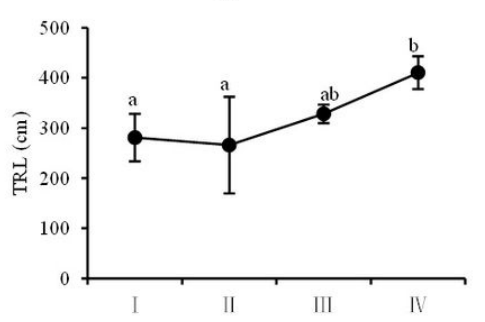

C

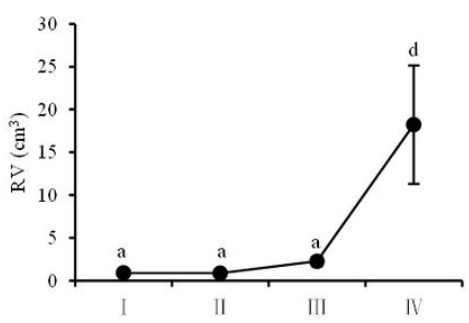

E

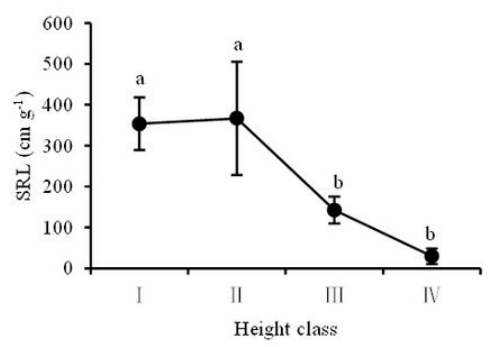

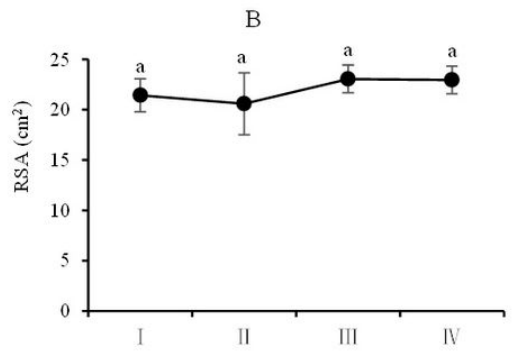

D

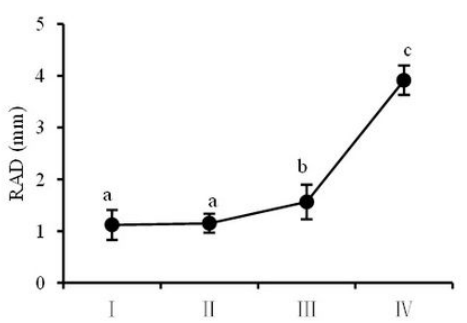

F

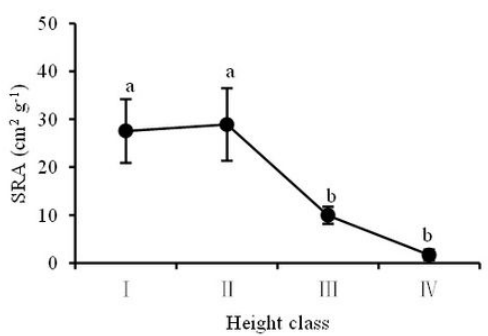

Figure 4

Changes of root traits with the increase of seedling height of Quercus acutissima. A: TRL; B: RSA; C: RV; D: RAD; E: SRL; F: SRA 

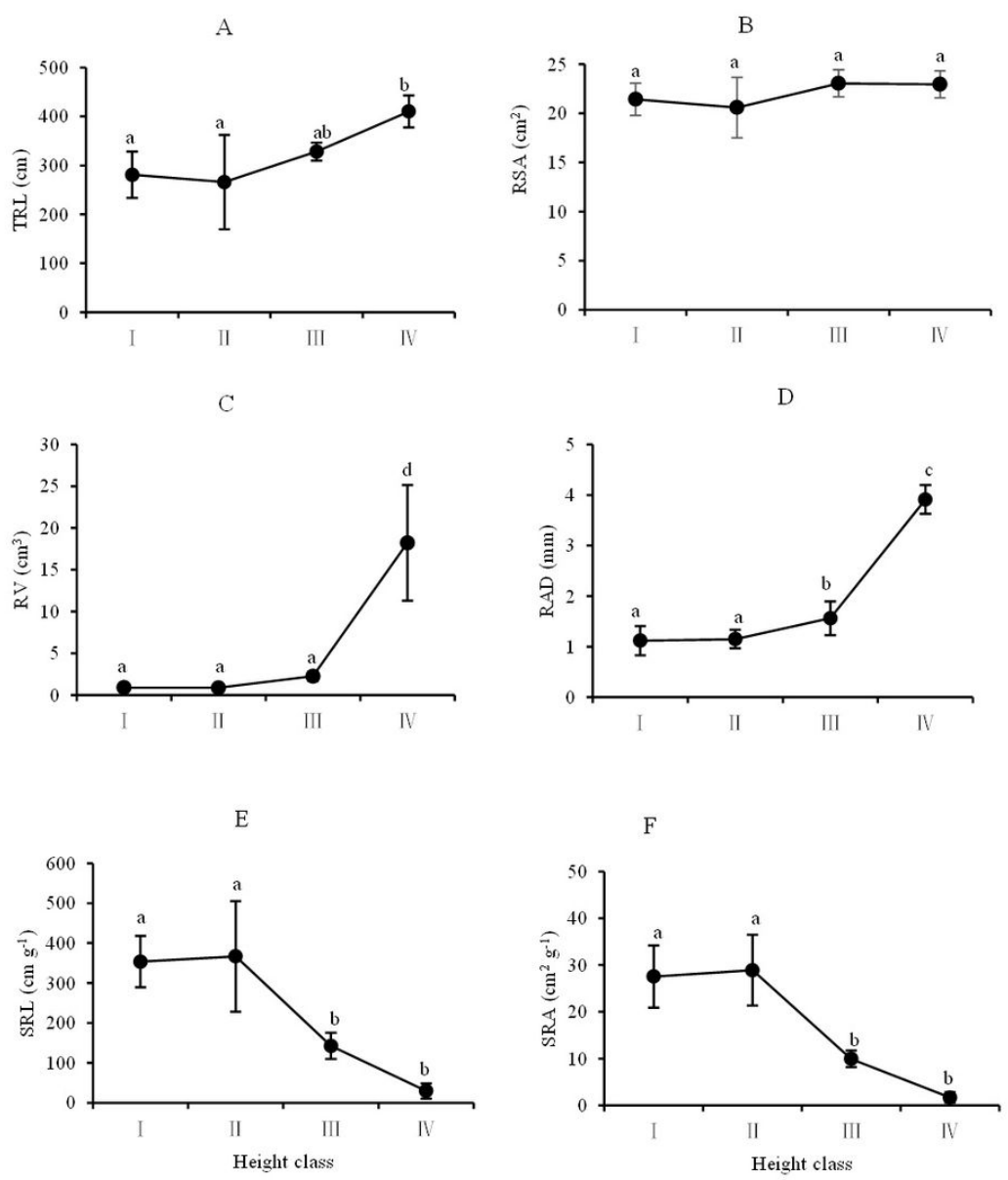

Figure 4

Changes of root traits with the increase of seedling height of Quercus acutissima. A: TRL; B: RSA; C: RV; D: RAD; E: SRL; F: SRA

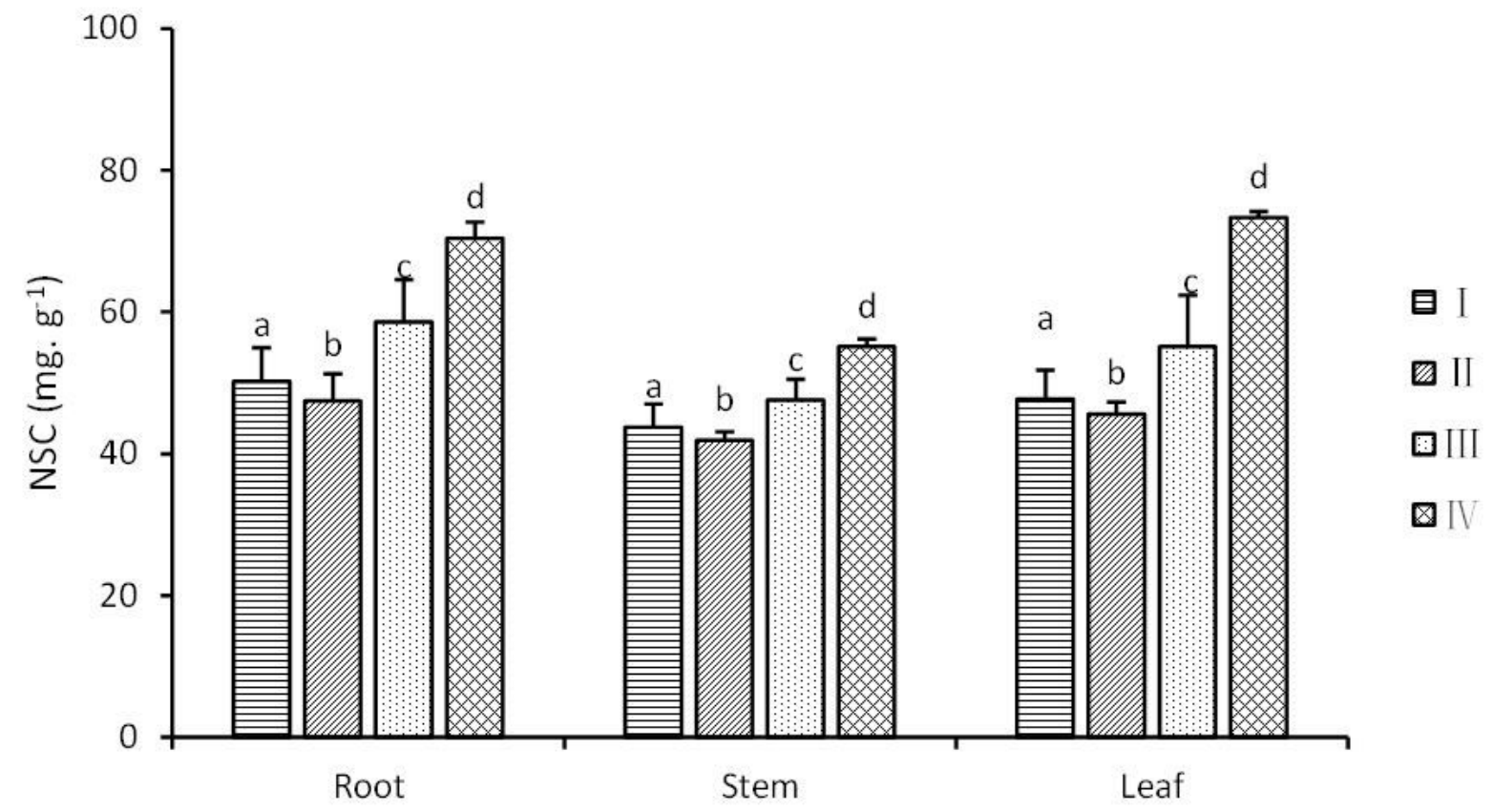


Figure 5

Changes of the content of non-structural carbohydrates of root, stem and leaf with the increase of seedling height of Quercus acutissima

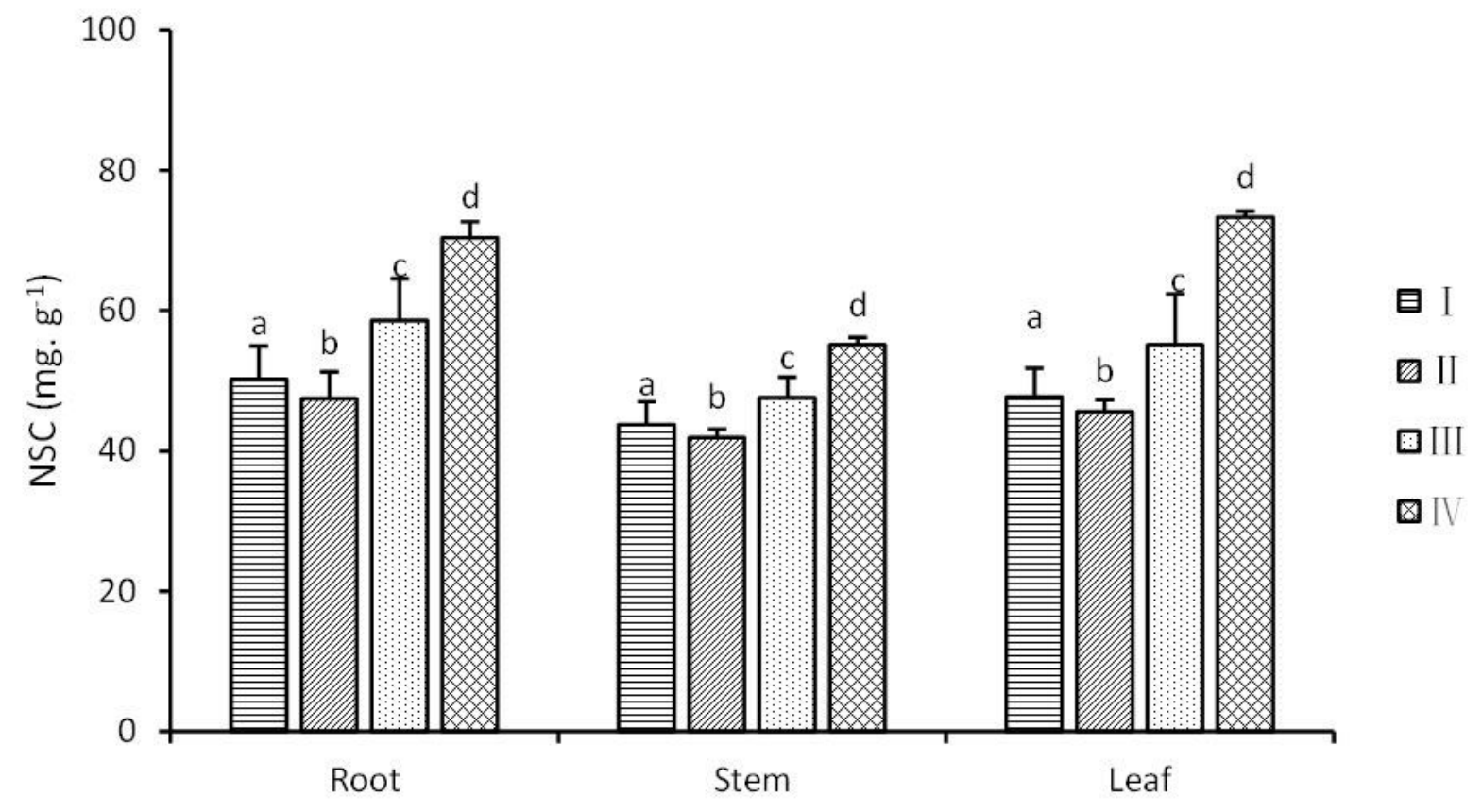

Figure 5

Changes of the content of non-structural carbohydrates of root, stem and leaf with the increase of seedling height of Quercus acutissima

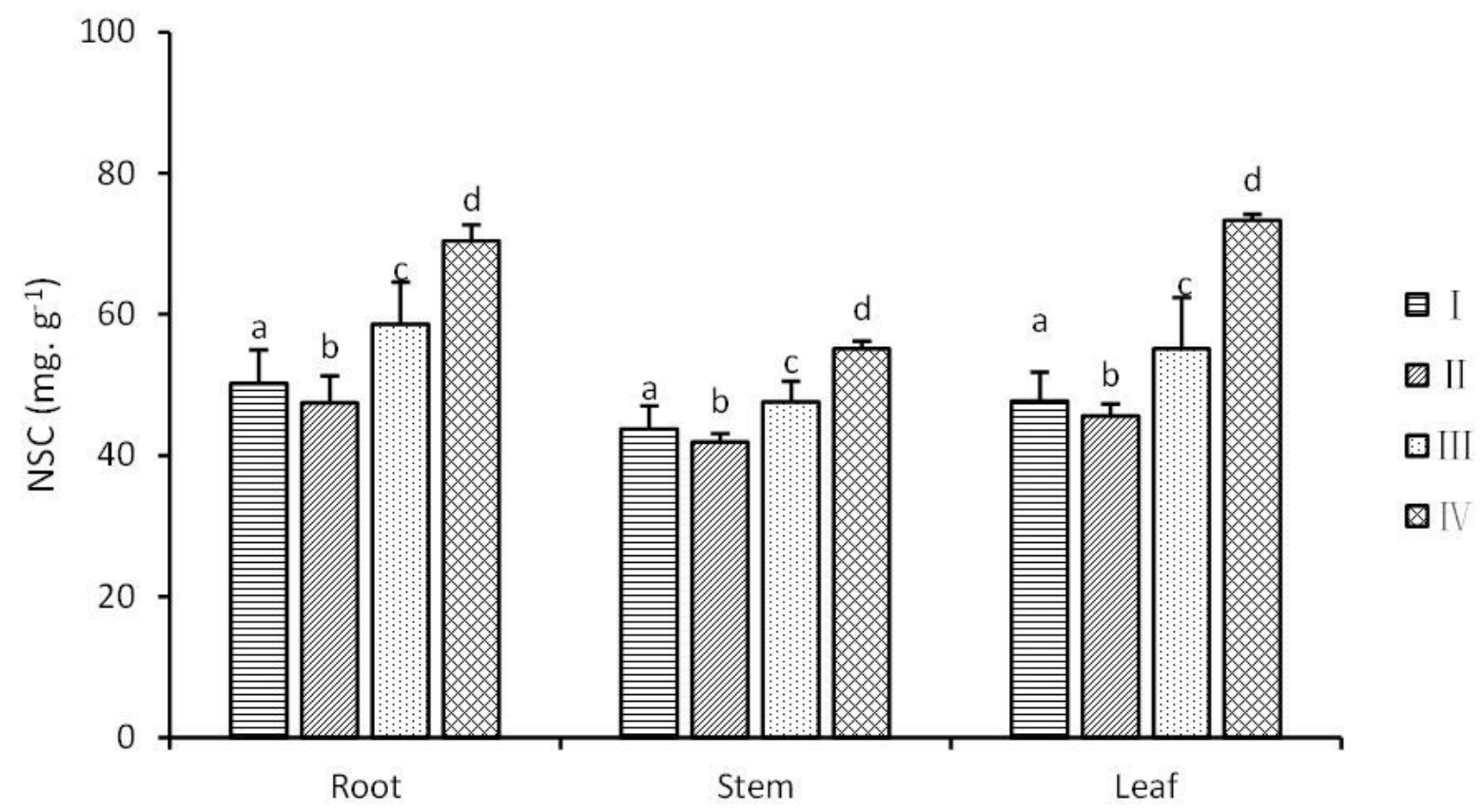

Figure 5

Changes of the content of non-structural carbohydrates of root, stem and leaf with the increase of seedling height of Quercus acutissima 